\title{
Ob sedemdesetletnici dopisnega člana Slovenske akademije znanosti in umetnosti dr. Ludvika Karničarja
}

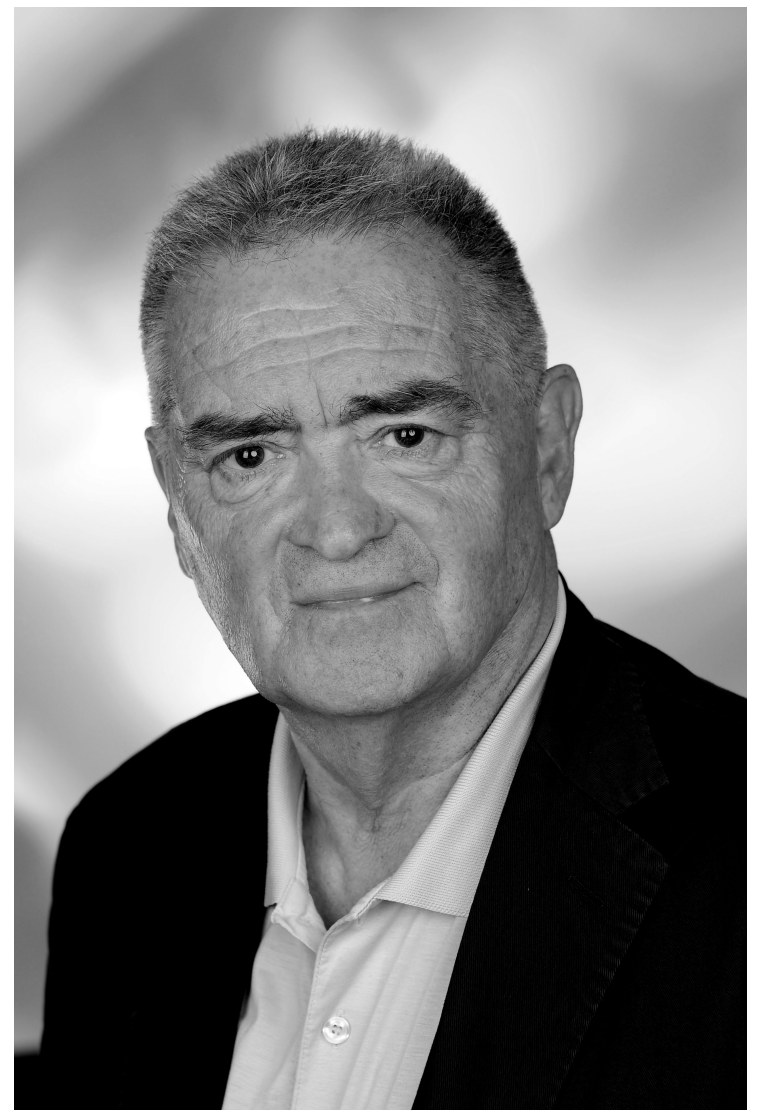

23. avgusta letos je bila ob bistrem potoku na avstrijskem Koroškem, pri Kovaču, v slovenski gostilni pod Obirjem, posebna priložnost - naš spoštovani in dragi kolega, priznani slavist, ugledni kulturolog, upokojeni profesor graške slovenistike in dopisni član SAZU, v domačem obirskem okolju in domači družini vedno 
dobrodošli in priljubljeni Ludvik Karničar je v krogu domačih, prijateljev in sodelavcev praznoval sedemdeseti rojstni dan. Vsi zbrani smo mu ob jubileju iskreno čestitali in mu zaželeli: »Še na mnogaja leta! Dragi Ludvik, Bog Vas živi!«

Ob taki obletnici, v najboljših letih življenja, ne zadoščajo le običajne besede, ki z vseh strani odmevajo in se ponavljajo. Potrebno je povedati nekaj več. Potrebno se je ozreti nazaj, na prehojeno pot, se zamisliti in spomniti, kako je naš jubilant sam premagoval številne ovire in napore, da je kot pokončni, zavedni in verni Slovenec dosegal svoje cilje, ki so ga iz topline domače rojstne hiše staršev, bratov, sester, izvabili v drugačna, neobčutljiva okolja, v širni evropski svet učenosti, znanosti in kulture. To bi nam znal in mogel le on sam slikovito, s kancem humorja, s pogledom iz obirskih višin na zamegljene nižave, izčrpno odkrivati in komentirati.

Jaz se bom omejila le na njegovo študijsko obdobje, na začetke njegovega uspešnega strokovnega vzpona pri študiju slavistike in prevajalstva na graški Univerzi. Srečala sem ga leta 1977/78 kot gostujoča lektorica slovenskega jezika na Inštitutu za slavistiko v Gradcu. Tedaj sem že imela za seboj neko lastno spoznanje o koroških Slovencih kot pripadnikih manjšine v Avstriji. V tem času mi, slavisti, pa tudi drugi slovenski državljani tedanje države (SFRJ) nismo skoraj nič vedeli o slovenskih rojakih »čez mejo«, saj neuradnih stikov z matičnim narodom skoraj ni bilo, če so bili prikriti, so pa bili zelo nevarni ...

Ko sem bila po smrti dr. Pivka, dunajskega univerzitetnega učitelja za slovenščino, na povabilo tamkajšnjega Inštituta za slovansko filologijo leta 1967 do konca leta 1968 (za tri semestre) z ljubljanskega Oddelka za slovanske jezike in književnosti poslana na Dunaj, da bi premostila časovno vrzel do zaključenega doktorskega študija dr. Pavla Zdovca (po letu 1969 je bil na to mesto učitelja za slovenski jezik uradno nameščen), nisem o svojih slušateljih, večinoma abiturientih celovške Zvezne gimnazije za Slovence, vedela ničesar. Tudi tega ne, kdo je tolikokrat s spoštovanjem omenjani dr. Jožko Tischler. Nekaj časa je bil med menoj in slušatelji neprodoren zid. Komaj sem govorila. Hromili so me njihovi nezaupljivi, skoraj porogljivi pogledi, končno pa mi je le uspelo najti primerne besede, ki so nas spravile v smeh. Tako smo se prepoznali, spoznali smo, da smo vsi eno, da smo vsi Slovenci - in postali smo prijatelji. Obiskovala sem z njimi tedaj zelo dejavni Klub koroških Slovencev na Dunaju in tako spoznavala takratne travme pravzaprav v čudni izolaciji živečih koroških Slovencev ... Zelo so me prizadele! Izdajali in pisali so v tem času svojo leposlovno revijo Mladje, na Koroškem se je začenjal boj za table s slovenskimi krajevnimi imeni in dostikrat sem slišala boleč očitek, kako smo mi, matični narod, nanje "pozabili«.

Kar sem mogla, sem napravila po vrnitvi v Ljubljano, da bi se koroškim študentom vsaj strokovne poti na naš Oddelek v Ljubljano odprle. In res so od takrat dalje posamezni slušatelji, slavisti in zgodovinarji, vsako leto prihajali na ljubljanski Poletni seminar za tuje slaviste na naš Oddelek za slovanske jezike in književnosti na Filozofski fakulteti (osnovan je bil 1. 1966). To seveda ni bilo ne vem kaj, vendar je bil »led prebit« in stiki s slavisti, zgodovinarji in geografi so oživeli (zlasti po zaslugi dr. Boga Grafenauerja in dr. Vlada Klemenčiča, ki sta bila s Koroško tudi sorodstveno povezana). Dunajski Klub koroških Slovencev je obiskal tedaj tudi priznani, pogumni novinar dnevnika Delo, pesnik in pisatelj Jože Snoj, ki je za slovensko javnost prvi o Klubu obelodanil več tehtnih prispevkov. 
Na Filozofski fakulteti pa je bila osnovana tudi Komisija za stike s Slovenci v zamejstvu. Vsako leto so med Božičem in novim letom v Celovcu potekali Koroški kulturni dnevi s predavanji na aktualne teme, ki so jih pripravili tako koroški kot ljubljanski predavatelji.

Ko sem leta 1977/78, že kot docentka, v isti vlogi za eno leto prišla na Inštitut za slavistiko v Gradec, sem v tamkajšnjem okolju že poznala predstojnika, dr. Stanislava Hafnerja, in tedaj še asistenta dr. Erika Prunča, srečala sem pa tudi slušatelja diplomanta, gospoda Ludvika. Zbiral in pripravljal je narečno gradivo z obirskega območja za svojo disertacijo. Spominjam se, da sva skupaj poslušala, zapisovala vsebinsko pretresljive narečne posnetke. Seznanjala sem ga s transkripcijskimi pravili zapisovanja narečnih glasov, uveljavljenih pri delu za Slovenski in Slovanski lingvistični atlas (SLA in OLA), ki sta takrat nastajala in sem pri tem delu sodelovala.

V spominu mi je ostala zlasti posneta zgodba o nekdanjem obirskem vojaku, ki je bil v drugi svetovni vojni na ruski fronti nekje v Ukrajini. V četi je bil za kuharja in k njemu se je priplazil nek sestradani otrok, ki se ni dal odgnati. Tvegal je in mu na skrivaj dajal jesti. Potem je prišel ukaz za umik. Otroka je odpeljal na samotno jaso in ga tam pustil samega ... Ni mogel drugače! Še ko se je po tolikih letih spominjal tega pretresljivega dogodka, se je jokal ... Tako sem odkrila mehkobo koroške duše, njegovo sočutje, dobrosrčnost, veliko trpljenje in - tveganje! Ne le njegovo, marveč mnogih koroških rojakov, ki so se morali proti svoji volji podrejati in uklanjati nesprejemljivim ukazom ... Tako sem dojela, kaj pomeni neprestano »duhovno nasilje« nad slovenskimi deželani Koroške. Skušala sem doumeti, kaj pomeni biti dan na dan na preizkušnji: ali zatajiti ali izpostaviti svojo materinščino, svojo etnično pripadnost, svojo identiteto, saj to ni ostajalo brez posledic! Ali ne pomenijo takšne vsakdanje razmere za človeka trajno »lomljenje hrbtenice«? Res! Koroških Slovencev je, na žalost, vedno manj, so pa vsi pokončni, preizkušeni, zavedni. In vrednote prednikov so jim dragocene, svete! Lahko se mi od njih učimo! Zato sem slovenske koroške rojake vedno na poseben način dobronamerno spremljala, jih skušala razumeti in ohranjati z njimi stike, tako tudi z našim jubilantom.

Ko sem v Gradcu videla, da slušatelj doktorand Ludvik poleg svojega raziskovalnega dela opravlja pod »nujno« še druge obveznosti, sem slutila, da obojemu ne bo kos. Predlagala sem predstojniku, prof. Hafnerju, da bi njegov doktorand s štipendijo za eno leto odšel v Ljubljano. To se je uresničilo in res je v Ljubljani v miru dokončal disertacijo ter dosegel doktorat znanosti. Disertacija Der Obir-Dialekt in Kärnten. Die Mundart von Ebriach/Obirsko im Vergleich mit den Nachbarmundart von Zell/Sele im Trögern/Korte pa je kasneje (leta 1990) izšla pri Avstrijski akademiji znanosti kot monografija o obirskem dialektu. Delo trajne znanstvene vrednosti, ki je gospoda dr. Ludvika Karničarja usposobilo za sodelovanje pri znamenitem Projektu za inventarizacijo leksike slovenskega ljudskega jezika oz. govorov Koroške, ki sta ga jezikoslovno zelo inovativno in znanstveno zahtevno zasnovala že pokojna dr. S. Hafner in dr. E. Prunč. Tovrstno raziskovalno delo in dejavno, trajno praktično udejstvovanje na področju prevajalstva sta dr. Karničarju zagotovila asistentsko mesto oz. sodelovanje na Avstrijskem inštitutu za vzhodnoevropsko in jugovzhodnoevropsko zgodovino (od leta 1986 do 1989), po 
odhodu dr. Erika Prunča na Inštitut za translatologijo pa na Inštitutu za slavistiko tudi nadaljnjo slavistično univerzitetno kariero - od asistenta do izrednega univerzitetnega profesorja, vse do upokojitve pred petimi leti. Za njim so se perspektive za slovenistiko na graški Univerzi, žal, zožile.

Dr. Karničar je bil »gonilna sila« Projekta za inventarizacijo slovenskega besedišča, pri katerem je končno ostal sam. Zelo se je poglabljal v slovensko besedišče Koroške v sočasnem in zgodovinskem uvidu. »Obrnil« je tudi Gutsmanov Deutsch-Windisches Wörterbuch (iz leta 1789), tj. izpostavil slovenske geselske besede, pripravil, uredil in pri dunajski Akademiji znanosti v letih 1982-2012 izdal na podlagi zbranega slovenskega besedja iz Projekta sedem zvezkov Tesaurusa (od A do Mi), Thesaurus der slowenischen Volkssprache in Kärnten, Alfabetarij k Tezauru slovenskega ljudskega jezika na Koroškem pa je sestavil v sodelovanju z dr. Andrejko Žejn in ga je lani (leta 2018) izdala Slovenska akademija znanosti in umetnosti (SAZU) v Ljubljani.

Kot razgledan in praktični prevajalec vseh zvrsti slovenskega jezika (tako publicističnih, pravnih kot ekonomskih) je sodeloval tudi pri Pravnem nemško-slovenskem (leta 1989) in slovensko-nemškem slovarju dr. Pavla Apovnika (leta 1996), delu izjemne vrednosti, in še bi lahko naštevali.

Napisal je vrsto tehtnih sociolingvističnih razprav, ki so izšle v nemških in slovenskih strokovnih zbornikih. Z izjemnim posluhom za jezikoslovna, zgodovinska in kulturološka vprašanja je v Gradcu organiziral vrsto mednarodnih simpozijev in srečanj, spominskih prireditev. Tako je na palači nekdanje jezuitske univerze oskrbel tudi spominsko ploščo prvemu učitelju slovenščine na graški stolici, Janezu Nepomuku Primicu (leta 2011). Organiziral je vsakoletne kulturološke ekskurzije $\mathrm{s}$ študenti v slovenski in slovanski prostor in $\mathrm{z}$ rojaki poromal v slovenska božjepotna središča. Z eno besedo: bil je vedno, in ostal, vsestransko komunikativna osebnost, »z dušo« na vseh področjih delovanja. Obvlada vsak »govorni položaj«! Mislim, da nima sovražnikov, ne med rojaki, ne med nemškimi sodeželani, pa tudi ne med ženskami ...

Ob svojem slovenističnem pedagoškem delu s študenti na graški fakulteti se je potrjeval s strokovnim slovenističnim in slavističnim znanjem (knjižna slovenščina, ruščina, hrvaščina), uporabljal pa je tudi svoje bogate izkušnje iz prevajalstva (odlikuje ga odlično znanje glavnih evropskih jezikov) in tako bistveno razširjal študijsko obzorje slušateljev, ki jih je znal pritegniti s svojo širino, duhovitostjo, vedrino in človeško toplino. Kot slavist-slovenist je vedno izvirno, s posluhom za sodobna družbena vprašanja koroškega dvojezičnega prostora, izpeljeval svoje naloge in svoje zamisli.

Vendar slovenistika s sociolingvistiko in z domoznanstvom ni bila edino njegovo ustvarjalno področje. Izvrstno je te vednosti interdisciplinarno povezoval z glasbo. V ta sklop sodi njegovo sodelovanje z glasbenim etnologom dr. Engelbertom Logarjem. Skupaj sta uredila in izdala do leta 2019 že 44 zvezkov gradiva serije Pesmi in glasba z južne Koroške. Z osebnim, občutenim vrhunskim petjem, saj je prejel tudi ta žlahten božji dar, pa je povsod, kjer je zapel, poskrbel za dobro voljo in s tem prispeval k utrjevanju trajnih prijateljskih vezi - tako na Koroškem kot v Sloveniji, bodisi na glasbeno-akademski ali na ljudski ravni ... Samo pomislimo, kaj pomeni peljati se, dokler je bil odgovoren za zbor, vsak teden iz Gradca na 
Obirsko, da lahko v župnijski cerkvi zapoje pri slovenski nedeljski maši! Kakšna zvestoba veri, maternemu jeziku in rojstnemu kraju!

Svojo predanost glasbi in petju je jubilant potrdil tudi s tem, da je na graškem pokopališču St. Leonhard skupaj z gospodom I. Martelancem dal postaviti nov nagrobnik prvemu profesorju slovenistu graške univerze, dr. Karlu Štreklju, zaslužnemu, načrtnemu zbiralcu in izdajatelju Slovenskih narodnih pesmi (leta 2014), za tem pa na pokopališču St. Peter poskrbel še za postavitev novega spomenika Slovencu, zdravniku, skladatelju in glasbeniku dr. Benjaminu Ipavcu, v sodobnosti pri nas preveč pozabljenemu ustvarjalcu slovenske domovinske zborovske pesmi 19. stoletja (leta 2018).

Gospod dr. Ludvik Karničar je bil leta 2017 za svoje zaslužno znanstveno in požrtvovalno kulturološko delo imenovan za dopisnega člana Slovenske akademije znanosti in umetnosti. Istega leta mu je predsednik Republike Slovenije Borut Pahor podelil red za zasluge, in sicer za trud pri ohranjanju slovenistične tradicije na graški univerzi. Leta 2017 je od Občine Komen prejel tudi Štrekljevo nagrado. To podeljujejo "posameznikom ali skupinam za življenjsko delo ali izjemne dosežke na področju zbiranja in ohranjanja slovenskega ljudskega blaga v besedi in pesmi«.

Tak je njegov presenetljivi družbeni vzpon od obirskega šolarja, ki se je (na vse pretege, kot je sam dejal) branil šole, do znanstvenika-akademika! Pa ne samo akademika, marveč tudi plemenitega, dobrosrčnega človeka, ki zna mirno nositi tudi tegobe življenja, kot je omajano zdravje. Pravi, da je slovenstvo nekaj edinstvenega, izbranega, podobno kot judovstvo, slovenščina pa kot hebrejščina arhaična in originalna; zato naj bi bila vsem, ki nase kaj dajo, srčna zadeva, vredna najglobljega spoštovanja!

Tak kot je, ostaja zgled rojakom na Koroškem in vsem nam Slovencem. Za vse mu gre čast in zahvala!

Ljubljana-Obirsko, 23. 8. 2019

Martina Orožen 